\title{
Exposure to cyantraniliprole causes mortality and disturbs behavioral and respiratory responses in the coffee berry borer (Hypothenemus hampei)
}

\author{
Angelica Plata-Rueda, ${ }^{a}$ Luis Carlos Martínez, ${ }^{\mathrm{b}}$ Brenda Karina R Da Silva, ${ }^{\mathrm{a}}$ \\ José C Zanuncio, ${ }^{c}$ Maria Elisa de S Fernandes, ${ }^{a}$ Raul Narciso C Guedes ${ }^{c} \odot$

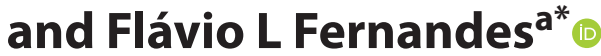

\begin{abstract}
BACKGROUND: Hypothenemus hampei Ferrari (Coleoptera: Curculionidae) is the main pest of coffee due to the damage caused to coffee berries. Effective management methods and prevention of insecticide resistance are urgently needed against this insect. Bioassays were conducted to assess the effects of the diamide insecticide cyantraniliprole on $\mathrm{H}$. hampei. Cyantraniliprole is the most recent compound registered against this species after the phasing out of endosulfan, the main insecticide historically used against the coffee borer for the past 30 years. Toxicity, survival, progeny production, respiration rate, and behavioral responses to cyantraniliprole were evaluated.
\end{abstract}

RESULTS: Cyantraniliprole was toxic to adult $H$. hampei $\left(\mathrm{LC}_{50}=0.67 \mathrm{mg} \mathrm{mL}^{-1}\right.$ and $\left.\mathrm{LC}_{90}=1.71 \mathrm{mg} \mathrm{mL}^{-1}\right)$. Adult survival was $95 \%$ without exposure to cyantraniliprole, decreasing to $52 \%$ in insects exposed to $\mathrm{LC}_{50}$ cyantraniliprole and $27 \%$ in insects treated with $\mathrm{LC}_{90}$ cyantraniliprole. Furthermore, $H$. hampei showed reduced mobility on insecticide-treated surfaces. The insecticide also led to a decrease in the respiration rate of $\mathrm{H}$. hampei for up to $3 \mathbf{h}$ after exposure, altering behavioral responses and locomotor activity.

CONCLUSION: Cyantraniliprole exhibits lethal and sublethal effects on $\boldsymbol{H}$. hampei and can be used in rotation in integrated pest management programs for control of this species in coffee cultivation systems.

(C) 2019 Society of Chemical Industry

Keywords: anthranilic diamides; larval production; pest control; respiration rate; survivorship; toxicity

\section{INTRODUCTION}

Hypothenemus hampei Ferrari (Coleoptera: Curculionidae) is the most damaging pest of coffee berries worldwide. ${ }^{1}$ The insect is native to Africa but has spread to coffee-producing countries in the Americas as a result of the introduction of infested seeds. ${ }^{2}$ Hypothenemus hampei females colonize immature and mature berries of Coffea arabica Linnaeus and Coffea canephora Linnaeus (Gentianales: Rubiaceae). ${ }^{3}$ Adults attack 8-32-week-old coffee berries by tunneling into the endosperm, where females deposit their eggs. Consequently, damage caused by $H$. hampei reduces the yield and quality of the final product, resulting in considerable economic losses for farmers. ${ }^{4}$ Damage caused by $\mathrm{H}$. hampei creates entry sites into coffee berries for phytopathogens, ${ }^{5}$ such as Erwinia stewartii (Smith) and Erwinia salicis (Day) Chester (Enterobacteriaceae), Aspergillus niger van Tieghem (Trichocomaceae), and Fusarium solani (Mart.) Sacc. (Nectriaceae). 2,6,7

In Brazil, control methods including the use of entomopathogenic fungi and ethanol/methanol traps have not been effective against $H$. hampei populations. ${ }^{8}$ The insect completes its entire life cycle within the seed of the coffee berry, making control difficult. Because of the high level of infestation and rapid spread of $H$. hampei in Brazilian coffee farms, the use of insecticides is common practice. ${ }^{9}$ Female $H$. hampei lay their eggs and crawl out of the berry during the inter-harvest period, then fly to find and colonize other berries. It is during this period that they can be exposed to chemical agents. ${ }^{10}$ Insecticides such as $\alpha$-cypermethrin, chlorpyrifos, cyfluthrin, deltamethrin, dieldrin, fenpropathrin, thiamethoxam, and triazophos have been used to control H. hampei, but endosulfan is the preferred compound

\footnotetext{
* Correspondence to: FL Fernandes, Instituto de Ciências Agrárias, Universidade Federal de Viçosa, 38810-000 Rio Paranaíba, Minas Gerais, Brazil. E-mail: flaviofernandes@ufv.br

a Instituto de Ciências Agrárias, Universidade Federal de Viçosa, Rio Paranaíba, Minas Gerais, Brazil

b Departamento de Biologia Geral, Universidade Federal de Viçosa, Viçosa, Minas Gerais, Brazil

c Departamento de Entomologia, Universidade Federal de Viçosa, Viçosa, Minas Gerais, Brazil
} 
due to its reliably high efficacy. ${ }^{2,11,12}$ Insecticides can act by contact and/or ingestion and cause neurotoxicity, which may be lethal. Application of insecticides is a common method used to manage pest populations and reduce coffee seed damage. ${ }^{12}$ However, insecticide resistance, particularly to endosulfan, has been reported in $\mathrm{H}$. hampei. $^{13}$

New insecticides with modes of action different from organochlorines and pyrethroids are needed to replace endosulfan and other currently used but less effective alternatives. These compounds are neurotoxins interfering with several neural targets including acetylcholine receptors, $\gamma$-aminobutyric acid (GABA) receptors and sodium channels, also potentially impairing respiratory and chitin synthesis pathways. ${ }^{14}$ Calcium channels are also a physiological target for insecticides because they regulate cell functions involving muscle contraction and neurotransmitter release. ${ }^{15}$ Coordinated muscle contraction involves activation of two distinct classes of calcium channels: voltage-gated channels that allow the entry of calcium, and ryanodine receptor channels that regulate the release of internal calcium stores. ${ }^{16}$ Anthranilic diamides are a novel class of chemical insecticides that act by promoting the release of intracellular $\mathrm{Ca}^{2+}$ stores through the activation of ryanodine receptors. ${ }^{17}$ Within this chemical group, cyantraniliprole is a broad-spectrum insecticide active on Coleoptera, Diptera, Hemiptera, Lepidoptera, and Thysanoptera. ${ }^{18-22}$ The efficacy of cyantraniliprole has been demonstrated against coffee pests, leading to its current pattern of frequent use..$^{23,24}$ However, it remains unknown how this insecticide affects locomotor activity and respiration in an insect as cryptic as $H$. hampei.

In this research, the effects of cyantraniliprole on $H$. hampei survivorship, larval production, respiration rate, and locomotor activity were evaluated. Our objective was to contribute to understanding how this diamide insecticide acts and achieves control of the coffee berry borer, as the current main replacement for endosulfan against this pest species.

\section{MATERIALS AND METHODS}

\subsection{Insects}

In the field, 849 adults of $H$. hampei (228 male, 621 female) were captured manually during the day between March and June 2017 at a 5-year-old coffee farm in the county of Viçosa, State of Minas Gerais, Brazil $\left(20^{\circ} 45^{\prime} \mathrm{S} 42^{\circ} 52^{\prime} \mathrm{W}\right)$. Borer presence was recognized by perforation of the berry or its presence at the fruit exit role. The collected insects were transferred from the field to the Laboratory of Biological Control of the Federal University of Viçosa for mass rearing. Adult borers were placed in plastic trays $(60 \mathrm{~cm}$ long $\times 40 \mathrm{~cm}$ wide $\times 12 \mathrm{~cm}$ high) in the dark at $25 \pm 1{ }^{\circ} \mathrm{C}, 70 \pm 10 \%$ relative humidity, and provided with mature 22 -week-old coffee berries. Coffee berries were observed daily until adult emergence. Newly emerged ( $24 \mathrm{~h}$ old) $\mathrm{H}$. hampei adults without apparent malformations were used in the bioassays.

\subsection{Concentration-mortality bioassay}

Cyantraniliprole $\left(100 \mathrm{~g} \mathrm{~L}^{-1}\right.$, Benevia ${ }^{\circledR}$ OD, Dupont, Alphaville, Brazil) was diluted in $10 \mathrm{~mL}$ of distilled water to obtain a stock solution. Six concentrations of cyantraniliprole were then prepared and used to assess insecticide toxicity and determine relevant toxicological endpoints; a dilution series of concentrations ranging from 0.3 to $10 \mathrm{mg} \mathrm{mL}^{-1}$ was used to determine concentration-mortality relationship and lethal concentration (LC). Distilled water was used as a control. Each solution
$(0.25 \mu \mathrm{L})$ was applied to the body of $50 \mathrm{H}$. hampei adults (48 $\mathrm{h}$ old) using a $1 \mu \mathrm{L}$ microsyringe (7001 KH, Hamilton Storage $\mathrm{GmbH}$, Domat/Ems, Switzerland). Insects were placed individually in glass vials $(2.5 \times 8 \mathrm{~cm})$ with a perforated cap for ventilation and absorbent paper, provided with coffee berries, and maintained in darkness. Three replicates of 50 insects each were used for each of the six concentrations tested following a completely random design. The number of dead adults in each vial was counted after $96 \mathrm{~h}$.

\subsection{Time-mortality bioassay}

Time-mortality bioassays for $H$. hampei using insecticide concentrations obtained in the concentration-mortality bioassay were carried out to further determine the lethal toxicity. Adults of $H$. hampei were exposed to $\mathrm{LC}_{25}, \mathrm{LC}_{50}, \mathrm{LC}_{75}$, and $\mathrm{LC}_{90}$ of cyantraniliprole, as determined in the toxicity bioassay, by recording mortality every $12 \mathrm{~h}$ for $96 \mathrm{~h}$. Exposure procedures, conditions, and number of insects were as described above for the toxicity test. Three replicates of 50 insects each were used for each insecticide concentration following a completely random design.

\subsection{Larval production}

Coffee berries were immersed for $5 \mathrm{~s}$ in cyantraniliprole concentrations corresponding to the $\mathrm{LC}_{50}$ and $\mathrm{LC}_{90}$. After drying for $24 \mathrm{~h}$, the berries were provided to adult insects (one berry for ten adult insects) allowing their colonization (i.e., egg-laying) inside glass vials $(2.5 \times 8 \mathrm{~cm})$. Ten berries containing one insect each were used for each concentration (and control). Single coffee berries colonized by $H$. hampei were X-rayed using an MX-20 specimen radiography system equipped with a 14-bit digital camera (Faxitron X-Ray Corp., Wheeling, IL, USA). The location of larvae within the coffee berry was digitally recorded throughout larval development at 1 , $5,10,15$, and 20 days after egg-laying. The number of live larvae per coffee berry was recorded.

\subsection{Behavioral responses}

Adult $H$. hampei were placed in a Petri dish $(90 \times 15 \mathrm{~mm})$ lined with filter paper (Whatman no. 1). The inner walls of the Petri dish were covered with polytetrafluoroethylene (Dupont ${ }^{\circledR}$, Barueri, SP, Brazil) to prevent insect escape. Behavioral response bioassays were conducted in arenas in which half was treated with $250 \mu \mathrm{L}$ of cyantraniliprole dissolved in distilled water $\left(\mathrm{LC}_{50}\right.$ or $\left.\mathrm{LC}_{90}\right)$; dishes treated with distilled water only were used as the control. One $H$. hampei adult was released in the center of the insecticide-treated arena (on filter paper) and kept in the Petri dish for $10 \mathrm{~min}$. Twenty-five insects were used for each lethal concentration, following a completely randomized design. For each insect, walking activity within the arena was recorded using a digital camcorder (XL1 3CCD NTSC, Canon, Lake Success, NY, USA) equipped with a $\times 16$ video lens (Zoom XL 5.5-88 mm, Canon). A video-tracking system (ViewPoint LifeSciences, Montreal, Quebec, Canada) was used to analyze the videos and measure the distance insects walked and the time spent resting on each half of the arena. Insects that spent $<1 \mathrm{~s}$ on the insecticide-treated half of the arena were considered repelled, whereas those that spent $<50 \%$ of the time on the insecticide-treated surface were considered irritated. ${ }^{25,26}$

\subsection{Respiration rate}

Respiration rate bioassays were conducted for $3 \mathrm{~h}$ after $\mathrm{H}$. hampei adults were exposed to cyantraniliprole ( $\mathrm{LC}_{50}$ and $\mathrm{LC}_{90}$ values), 
according to the procedures detailed in Section 2.2. Insects treated with distilled water were used as a control. Carbon dioxide $\left(\mathrm{CO}_{2}\right)$ production $\left(\mu \mathrm{LCO}_{2} \mathrm{~h}^{-1}\right.$ insect ${ }^{-1}$ ) was measured with a TR3C $\mathrm{CO}_{2}$ analyzer (Sable System International, Las Vegas, NV, USA) using methods adapted from previous studies. ${ }^{27,28}$ An adult of $H$. hampei (female or male) was placed in each respirometry chamber $(25 \mathrm{~mL})$ connected to a closed system. After insect acclimation, $\mathrm{CO}_{2}$ production was measured for $12 \mathrm{~h}$ at $27 \pm 2{ }^{\circ} \mathrm{C}$. Subsequently, compressed oxygen (99.99\% pure) was introduced into the chamber at $100 \mathrm{~mL} \mathrm{~min}^{-1}$ for $2 \mathrm{~min}$. The gas flow forces the $\mathrm{CO}_{2}$ through an infrared reader, which continuously measures the $\mathrm{CO}_{2}$ held inside the chamber. Before and after the experiment, $H$. hampei adults were weighed on an analytical balance (Sartorius BP 210D, Göttingen, Germany). Fifteen replicates were used for each insecticide treatment and control following a completely randomized design.

\subsection{Statistical analyses}

Concentration-mortality data were subjected to probit analysis, generating a concentration-mortality curve. ${ }^{29}$ Time-mortality data were subjected to survival analyses using Kaplan-Meier estimators (log-rank test) through Origin Pro v. 9.1 software. $^{30}$ The number of $\mathrm{H}$. hampei adults that survived until the end of the experiment was treated as censored data. Larval production and behavioral response data were analyzed by one-way analysis of variance (ANOVA), and Tukey's honestly significant difference (HSD) test was also used for comparison of means at the $5 \%$ significance level. Respiration rates were subjected to two-way ANOVA and Tukey's HSD test $(P<0.05)$. Larval production, behavioral response, and respiration rates were arcsine transformed to meet assumptions of normality and homoscedasticity. The experiments were conducted using a completely randomized design. Toxicity, larval production, behavioral response, and respiration rate data were analyzed using SAS for Windows v. 9.0.31

\section{RESULTS}

\subsection{Toxicity}

The concentration-mortality model used was suitable $(P>0.05)$, confirming the toxicity of cyantrantraniliprole to the coffee berry borer and allowing estimates of the desired toxicological endpoints for subsequent use (Table 1 ). Mortality remained $<1 \%$ in the control group.

\subsection{Survival analysis}

Survival analysis of $H$. hampei adults exposed to different lethal concentrations of cyantraniliprole indicated significant differences among cyantraniliprole concentrations (log-rank test; $\chi^{2}=65.13$; $\mathrm{df}=4 ; P<0.001)$; survival time decreased with insecticide concentration (Fig. 1). After $96 \mathrm{~h}$ of exposure, survival was $95.7 \%$ for unexposed adults decreasing to $65.2 \%$ at $\mathrm{LC}_{25}, 52.4 \%$ to $\mathrm{LC}_{50}, 44.9 \%$ to $\mathrm{LC}_{75}$, and $27.8 \%$ to $\mathrm{LC}_{90}$.

\subsection{Larval production}

Exposure to cyantraniliprole reduced the number of live H. hampei larvae (Fig. 2). Hypothenemus hampei larvae were present in higher numbers in the control and $\mathrm{LC}_{50}$ groups, but in lower numbers at $\mathrm{LC}_{90}$. The number of larvae was different after 15 days $\left(F_{2,14}=13.61 ; P<0.001\right)$ and 20 days $\left(F_{2,14}=10.95 ; \quad P<0.001\right)$ (Table 2). We were not able to detect larvae before 15 days of development.
Table 1. Lethal concentrations of cyantraniliprole against Hypothenemus hampei after $24 \mathrm{~h}$ exposure obtained from probit analysis $(\mathrm{df}=5$, Slope $\pm \mathrm{SE}=1.143 \pm 0.53$, intercept $=2.032)$

\begin{tabular}{|lcccc|}
$\begin{array}{l}\text { No. of } \\
\text { insects }\end{array}$ & $\begin{array}{c}\text { Lethal } \\
\text { concentration }\end{array}$ & $\begin{array}{c}\text { Estimated } \\
\text { concentration } \\
\left(\mathrm{mg} \mathrm{mL}^{-1}\right)\end{array}$ & $\begin{array}{c}\text { 95\% } \\
\text { confidence } \\
\text { interval } \\
\left(\mathrm{mg} \mathrm{mL}^{-1}\right)\end{array}$ & $\begin{array}{c}\chi^{2} \\
(P \text {-value })\end{array}$ \\
\hline 150 & $\mathrm{LC}_{25}$ & 0.127 & $0.082-0.176$ & $14.91(0.79)$ \\
150 & $\mathrm{LC}_{50}$ & 0.670 & $0.571-0.759$ & \\
150 & $\mathrm{LC}_{75}$ & 1.136 & $0.882-1.348$ & \\
150 & $\mathrm{LC}_{90}$ & 1.716 & $1.353-2.109$ & \\
150 & $\mathrm{LC}_{99}$ & 2.621 & $1.879-4.025$ & \\
\hline
\end{tabular}

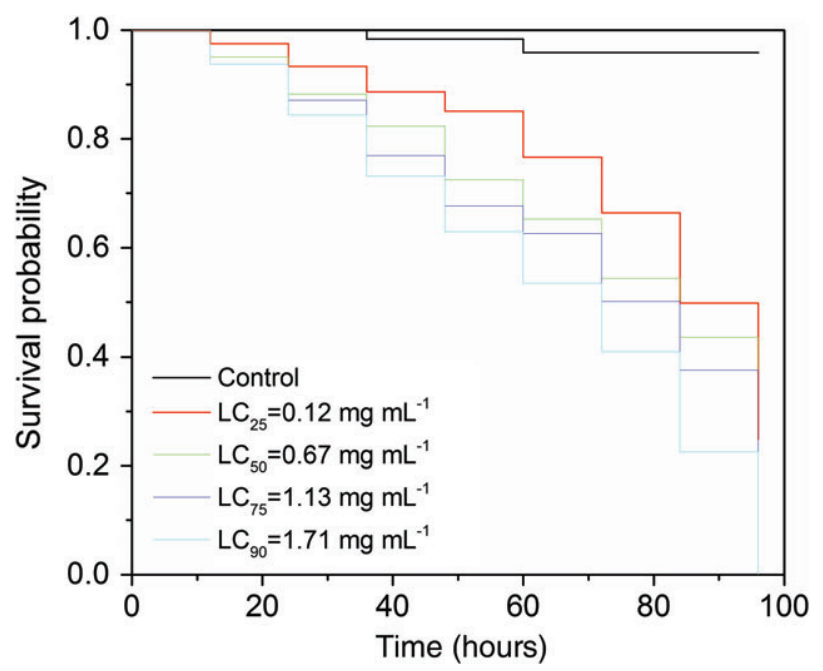

Figure 1. Survival curves of Hypothenemus hampei adults exposed to different lethal concentrations subjected to survival analyses using the Kaplan-Meier estimators log-rank test (log-rank $\left.\chi^{2}=65.13 ; P<0.001\right)$.

\subsection{Behavioral responses}

Representative walking tracks for $\mathrm{H}$. hampei adults released onto half-treated arenas are shown in Fig. 3. The distance traveled was higher in the control and $\mathrm{LC}_{50}$ exposure groups than under $\mathrm{LC}_{90}$ exposure. The resting period was longer in the control group than in the $\mathrm{LC}_{50}$ and $\mathrm{LC}_{90}$ groups $\left(F_{2,23}=9.54, P<0.001\right)$ (Fig. 4$)$. The distance traveled by $H$. hampei exposed to insecticide was greater than that of unexposed insects $\left(F_{2,23}=5.74 ; P<0.015\right)$ (Fig. 4).

\subsection{Respiration rate}

The respiration rate $\left(\mu \mathrm{LCO}_{2} \mathrm{~h}^{-1}\right.$ insect $\left.{ }^{-1}\right)$ of $\mathrm{H}$. hampei was different $\left(F_{2,89}=8.98, P<0.001\right)$ when exposed to chlorantraniliprole at $\mathrm{LC}_{50}$ and $\mathrm{LC}_{90}$, and decreased between 1 and $3 \mathrm{~h}$ (Fig. 5).

\section{DISCUSSION}

The toxicity of cyantraniliprole to the coffee berry borer, H. hampei was determined from bioassays performed under laboratory conditions. Cyantraniliprole was toxic to adult $H$. hampei and had a strong effect upon topical application $\left(\mathrm{LC}_{50}=0.67 \mathrm{mg} \mathrm{mL}^{-1}\right.$ and $\mathrm{LC}_{90}=1.71 \mathrm{mg} \mathrm{mL}^{-1}$ ). The insecticide caused mortality in $\mathrm{H}$. hampei in a concentration-dependent manner, as reported for other insects. ${ }^{17-19}$ Hypothenemus hampei individuals exposed to high concentrations of cyantraniliprole $\left(\mathrm{LC}_{50}\right.$ and $\left.\mathrm{LC}_{90}\right)$ displayed altered 

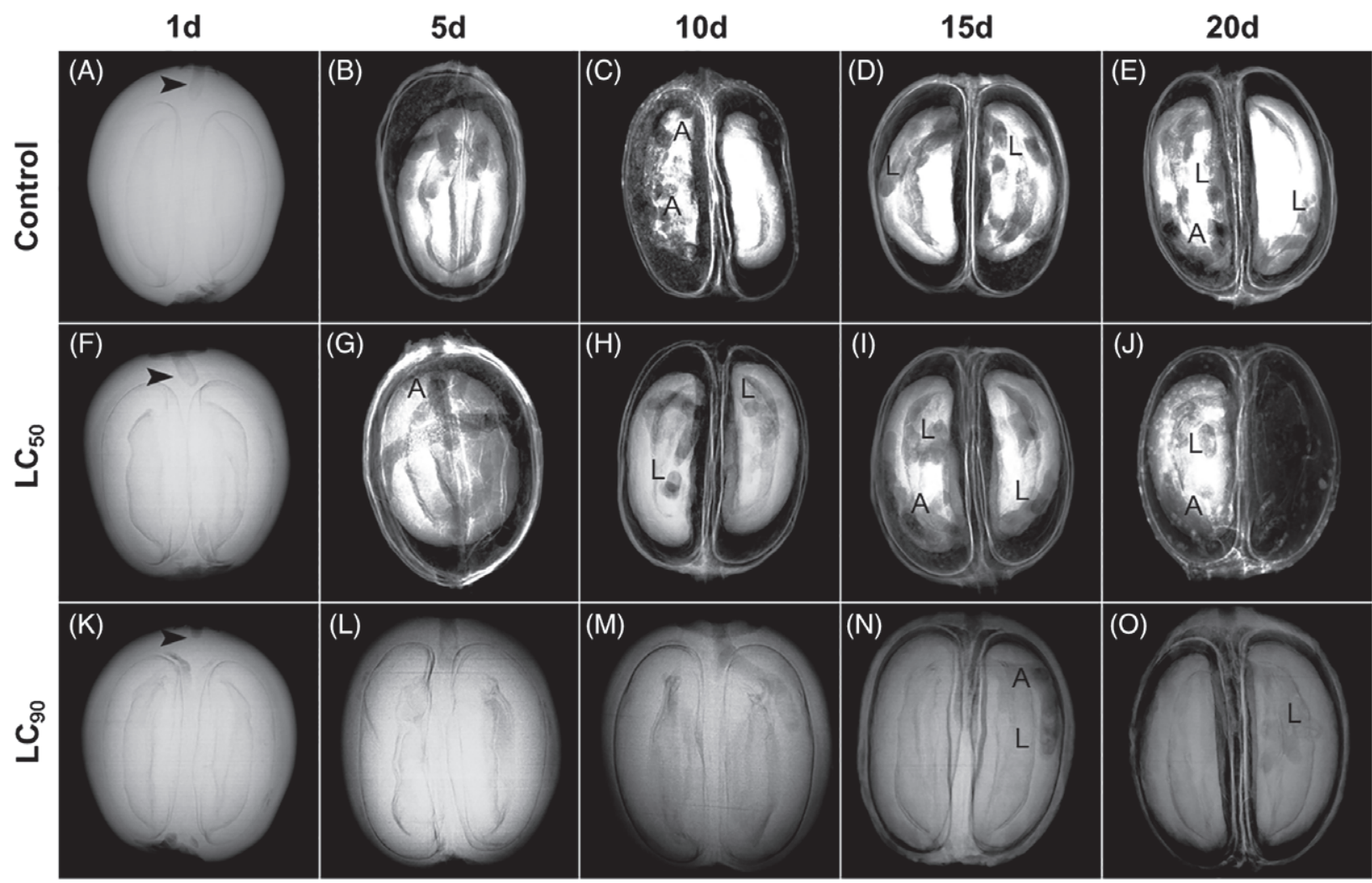

Figure 2. Temporal sequence of X-ray pictures showing the number of live Hypothenemus hampei (larvae and adults) within a single coffee berry colonized after 20 days exposure to cyantraniliprole. Larvae (L) and adults (A) are indicated, and arrows denote initial damage in coffee berry.

Table 2. Larvae of Hypothenemus hampei found in coffee berries treated with cyantraniliprole (control, $\mathrm{LC}_{50}$ and $\mathrm{LC}_{90}$ estimated values). Treatments (mean \pm SEM) differ at $\mathrm{P}<0.05$ (Tukey's mean separation test)

\begin{tabular}{lccc|} 
& & \multicolumn{2}{c}{ Insecticide treatments } \\
\cline { 3 - 4 } $\begin{array}{l}\text { Time after } \\
\text { exposure (days) }\end{array}$ & Control & $\mathrm{LC}_{50}$ & $\mathrm{LC}_{90}$ \\
\hline 15 & $3.07 \pm 0.71 \mathrm{a}$ & $3.42 \pm 0.73 \mathrm{a}$ & $0.21 \pm 0.15 \mathrm{~b}$ \\
20 & $4.62 \pm 0.95 \mathrm{a}$ & $4.25 \pm 0.58 \mathrm{a}$ & $0.43 \pm 0.24 \mathrm{~b}$ \\
\hline
\end{tabular}

Values in the same column with different letters show significant differences by Tukey's HSD test at the $P<0.05$ level.

locomotor activity. Some individuals suffered paralysis with no signs of recovery when exposed to $\mathrm{LC}_{90}$. In this case, symptoms in $\mathrm{H}$. hampei were consistent with the known effect of ryanodine receptor agonists. The susceptibility of other curculionid pests such as Anthonomus eugenii Cano, ${ }^{21}$ Dendroctonus ponderosae Hopkins, ${ }^{32}$ and Listronotus maculicollis Kirby ${ }^{33}$ may vary depending on the method of exposure to cyantraniliprole (contact or ingestion). In general, few insecticides are effective against $H$. hampei. Our findings highlight the need to adopt novel molecules for management of $H$. hampei, and this is reinforced by reports of insecticide resistance in this species. ${ }^{13}$

Extended periods of exposure to cyantraniliprole, from 12 to $96 \mathrm{~h}$, were needed to induce mortality in $\mathrm{H}$. hampei. Survival of $H$. hampei is associated with the slow action of cyantraniliprole. Anthranilic amides are slow-acting molecules that cause moderate topical and ingestion toxicity, ${ }^{34-36}$ whereas a more rapid response has been observed in sucking pests. ${ }^{19,20}$ In this case, scolytid beetles are able to feed but die later on. One possible explanation for
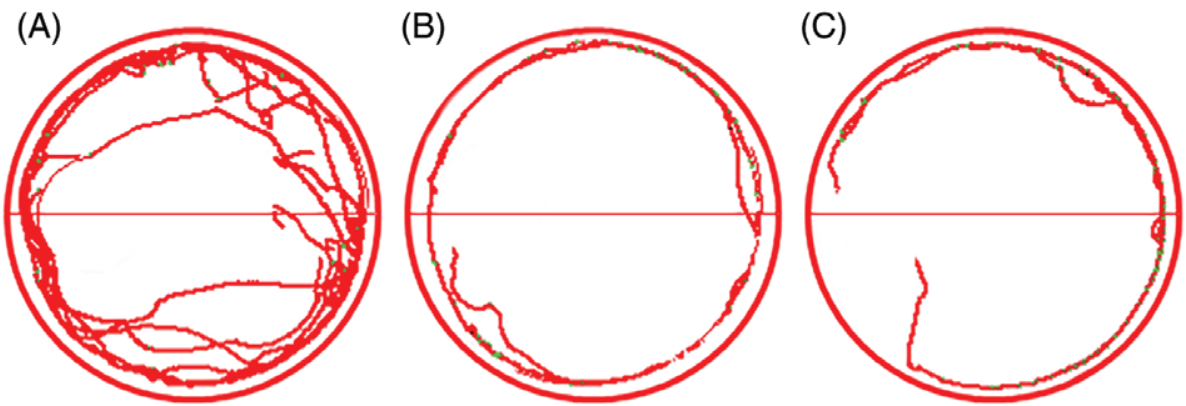

Figure 3. Representative tracks showing the walking activity of Hypothenemus hampei over a 10-min period on filter paper arenas half-impregnated with cyantraniliprole (upper half of each arena). Red tracks indicate high walking velocity; green tracks indicate low (initial) velocity. 

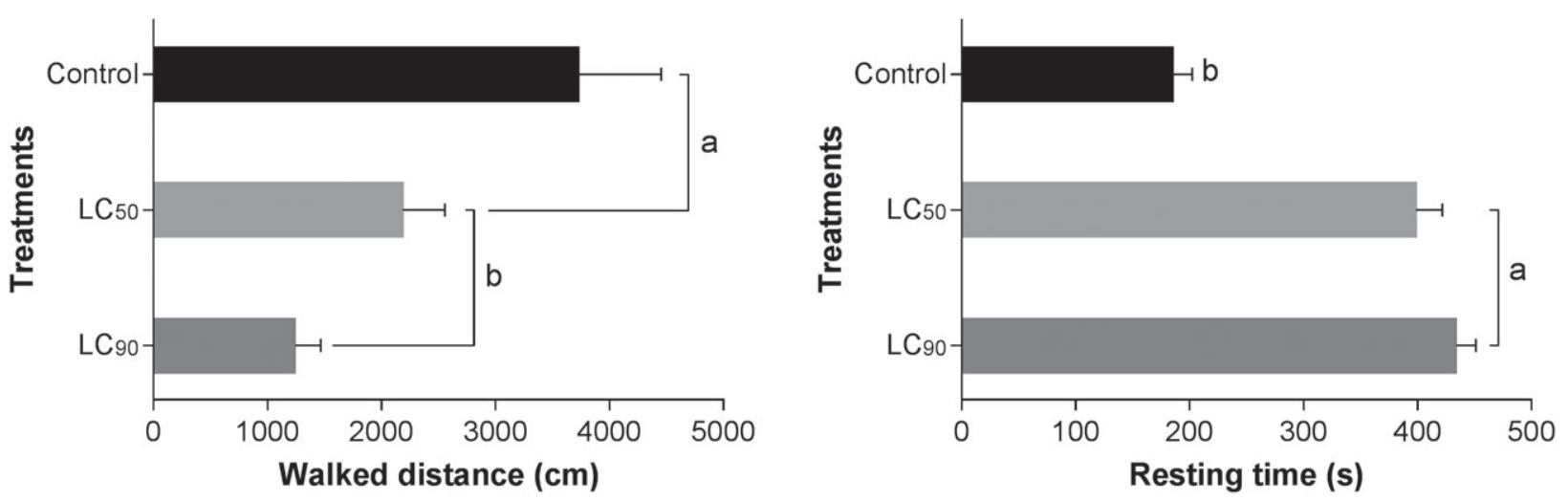

Figure 4. Distance walked and resting time (mean $\pm \mathrm{SEM}$ ) of Hypothenemus hampei subjected to cyantraniliprole (control, $\mathrm{LC}_{50}$ and $\mathrm{LC}_{90}$ estimated values) for 10 min. Treatments (mean \pm SEM) differ at $P<0.05$ (Tukey's mean separation test).

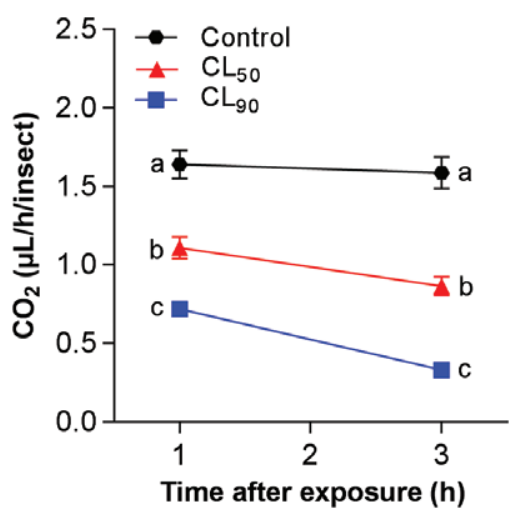

Figure 5. Respiration rate (mean $\pm \mathrm{SEM}$ ) of Hypothenemus hampei exposure to cyantraniliprole (control, $\mathrm{LC}_{50}$ and $\mathrm{LC}_{90}$ estimated values) for $3 \mathrm{~h}$. Treatments (mean \pm SEM) differs at $P<0.05$ (Tukey's mean separation test).

the insecticide's slow action is that efficacy may be affected by penetration of cyantraniliprole into the exoskeleton of $\mathrm{H}$. hampei compared with that of other insects. Our results showed that $H$. hampei had lower survival probability at cyantraniliprole concentrations $\geq 1.71 \mathrm{mg} \mathrm{mL}^{-1}$ during prolonged exposure.

The number of $H$. hampei larvae per coffee berry varied throughout the colonization period. The results show that the number of live larvae declined under $\mathrm{LC}_{90}$ exposure. The action of insecticides throughout the developmental stages has been reported in several insect pests, affecting intrinsic population growth rate, longevity, survival, and reproduction. ${ }^{37-39}$ Our study suggests that cyantraniliprole causes larvae mortality and compromises progeny production by adults of $H$. hampei.

The behavioral response assay indicated that cyantraniliprole had a substantial effect on $H$. hampei. Changes in walking patterns occur as a result of the action of toxic compounds on the nervous system, which either stimulate or reduce insect mobility. Various insect pests show altered behavioral responses when exposed to insecticides; insects are reported to leave toxic environments as soon as they detect toxic compounds. . $^{2740,41}$ Studies show that synthetic insecticides can disrupt recognition of the host substrate, influencing the olfactory orientation and walking behavior of insects. ${ }^{42-44}$ Volatile insecticides may enter insects through the spiracles and tracheae during respiration. ${ }^{45}$ Our results indicate that $H$. hampei exhibits behavioral avoidance by means of repellence to cyantraniliprole, minimizing contact with insecticide-contaminated surfaces. In addition, cyantraniliprole also impaired walking activity in the coffee berry borer indicating a significant sublethal effect that likely enhances exposure.

Cyantraniliprole negatively affected the respiration rate of $H$. hampei indicating physiological stress caused by the insecticide. Similar results have been reported for other insects exposed to insecticides. ${ }^{44,46,47}$ This decrease would be linked to the decrease in their behavioral response and locomotor activity. It was expected that higher levels of walking activity would result in higher metabolism and a higher respiration rate. Oxygen reduction has been related to the disruption of oxidative phosphorylation and respiratory processes. ${ }^{48,49}$ In this study, H. hampei adults exposed to cyantraniliprole had low respiration rates, which further unbalance the organism physiology.

The insecticidal potential of cyantraniliprole against $H$. hampei was studied. Our results show that cyantraniliprole causes high mortality, reduces survival time and progeny production, in addition to changing walking activity and lowering the respiration rate of $H$. hampei. Thus, cyantraniliprole exhibits lethal and sublethal effects on $H$. hampei and can be used as an alternative to other synthetic insecticides, aiding efforts to manage insecticide resistance.

\section{ACKNOWLEDGEMENTS}

This study was funded by the Brazilian research agencies National Council for Scientific and Technological Development (CNPq, grant no. 304198/2015-3), Coordination for the Improvement of Higher Education Personnel (CAPES), and Minas Gerais Research Foundation (FAPEMIG).

\section{REFERENCES}

1 Jaramillo J, Borgemeister C and Baker P, Coffee berry borer Hypothenemus hampei (Coleoptera: Curculionidae): searching for sustainable control strategies. Bull Entomol Res 96:223-233 (2006).

2 Damon A, A review of the biology and control of the coffee berry borer, Hypothenemus hampei (Coleoptera: Scolytidae). Bull Entomol Res 90:453-465 (2000).

3 Bustillo Pardey AE, A review of the coffee berry borer, Hypothenemus hampei (Coleoptera: Curculionidae: Scolytinae), in Colombia. Rev Colomb Entomol 32:101-116 (2006).

4 Moore D, Prior C, Present status of biological control of the coffee berry borer Hypothenemus hampei, in Proceedings of the Brighton Crop Protection Conference - Pests and Diseases, British Crop Protection Council., Thornton Heath, UK, pp. 1119-1124 (1988).

5 Reid JC and Mansingh A, Economic losses due to Hypothenemus hampei Ferr. during processing of coffee berries in Jamaica. Int J Pest Manage 31:55-59 (1985).

6 Sponagel KW, La broca del café Hypothenemus hampei en plantaciones de café robusta en la Amazonía Ecuatoriana. Wissenschaftlicher, Fachverlag, Giessen, Germany, pp. 191 (1994). 
7 Morales-Ramos JA, Rojas MG, Sittertz-Bhatkar H and Saldaña G, Symbiotic relationship between Hypothenemus hampei (Coleoptera: Scolytidae) and Fusarium solani (Moniliales: Tuberculariaceae). Ann Entomol Soc Am 93:541 - 547 (2000).

8 Silva FCD, Ventura MU and Morales L, Capture of Hypothenemus hampei Ferrari (Coleoptera, Scolytidae) in response to trap characteristics. Sci Agric 63:567-571 (2006).

9 Cure JR, Santos RH, Moraes JC, Vilela EF and Gutierrez AP, Fenologia e dinâmica populacional da broca do café Hypothenemus hampei (Ferr.) relacionadas às fases de desenvolvimento do fruto. An Soc Entomol Bras 27:325-335 (1998).

10 Baker PS, Ley C, Balbuena R and Barrera JF, Factors affecting the emergence of Hypothenemus hampei (Coleoptera: Scolytidae) from coffee berries. Bull Entomol Res 82:145-150 (1992).

11 Mansingh A and Rhodes LF, Bioassay of various formulations of insecticides on the egg and larval stages of the coffee berry borer Hypothenemus hampei Ferrari (Scolytidae: Coleoptera). Int J Trop Insect Sci 4:223-226 (1983).

12 Oliveira CND, Neves PMOJ and Kawazoe LS, Compatibility between the entomopathogenic fungus Beauveria bassiana and insecticides used in coffee plantations. Sci Agric 60:663-667 (2003).

13 Steichen JC and Brun LO, A molecular diagnostic for endosulfan insecticide resistance in the coffee berry borer Hypothenemus hampei (Coleoptera: Scolytidae). Bull Entomol Res 84:11-15 (1994).

14 Sparks TC and Nauen R, IRAC: mode of action classification and insecticide resistance management. Pestic Biochem Physiol 121:122-128 (2015).

15 Lahm GP, Selby TP, Freudenberger JH, Stevenson TM, Myers BJ, Seburyamo G et al., Insecticidal anthranilic diamides: a new class of potent ryanodine receptor activators. Bioorg Med Chem Lett 15:4898-4906 (2005).

16 Cordova D, Benner EA, Sacher MD, Rauh JJ, Sopa JS, Lahm GP et al., Anthranilic diamides: a new class of insecticides with a novel mode of action, ryanodine receptor activation. Pestic Biochem Physiol 84:196-214 (2006).

17 Selby TP, Lahm GP, Stevenson TM, Hughes KA, Cordova D, Annan IB et al., Discovery of cyantraniliprole, a potent and selective anthranilic diamide ryanodine receptor activator with cross-spectrum insecticidal activity. Bioorg Med Chem Lett 23:6341-6345 (2013).

18 Hardke JT, Temple JH, Leonard BR and Jackson RE, Laboratory toxicity and field efficacy of selected insecticides against fall armyworm (Lepidoptera: Noctuidae). Fla Entomol 94:272-278 (2011).

19 Jacobson AL and Kennedy GG, The effect of three rates of cyantraniliprole on the transmission of tomato spotted wilt virus by Frankliniella occidentalis and Frankliniella fusca (Thysanoptera: Thripidae) to Capsicum annuum. Crop Prot 30:512-515 (2011).

20 Foster SP, Denholm I, Rison JL, Portillo HE, Margaritopoulis J and Slater R, Susceptibility of standard clones and European field populations of the green peach aphid, Myzus persicae, and the cotton aphid, Aphis gossypii (Hemiptera: Aphididae), to the novel anthranilic diamide insecticide cyantraniliprole. Pest Manag Sci 68:629-633 (2012).

21 Caballero R, Schuster DJ, Smith HA, Mangandi J and Portillo HE, A systemic bioassay to determine susceptibility of the pepper weevil, Anthonomus eugenii Cano (Coleoptera: Curculionidae) to cyantraniliprole and thiamethoxam. Crop Prot 72:16-21 (2015).

22 Zhang R, Jang EB, He S and Chen J, Lethal and sublethal effects of cyantraniliprole on Bactrocera dorsalis (Hendel) (Diptera: Tephritidae). Pest Manag Sci 71:250-256 (2015).

23 De Souza JC, Reis PR, Silva RA, de Carvalho TAF and Pereira AB, Chemical control of the coffee berry borer with cyantraniliprole. Coffee $\mathrm{SCi}$ 8:404-410 (2013).

24 Reis PR, Toledo MA and Silva FMA, Cyazypyr ${ }^{T M}$ selectivity for three species of Phytoseiid for coffee and other relevant agricultural crops in Brazil. Agric Sci 5:298-303 (2014).

25 Cordeiro EMG, Corrêa AS, Venzon M and Guedes RNC, Insecticide survival and behavioral avoidance in the lacewings Chrysoperla externa and Ceraeochrysa cubana. Chemosphere 81:1352-1357 (2010).

26 Martínez LC, Plata-Rueda A, Colares HC, Campos JM, Dos Santos MH, Fernandes FL et al., Toxic effects of two essential oils and their constituents on the mealworm beetle, Tenebrio molitor. Bull Entomol Res 108:716-725 (2018).

27 Plata-Rueda A, Martínez LC, Dos Santos MH, Fernandes FL, Wilcken CF, Soares MA et al., Insecticidal activity of garlic essential oil and their constituents against the mealworm beetle, Tenebrio molitor Linnaeus (Coleoptera: Tenebrionidae). Sci Rep 7:46406 (2017).
28 Fiaz M, Martínez LC, da Silva Costa M, Cossolin JFS, Plata-Rueda A, Gonçalves WG et al., Squamocin induce histological and ultrastructural changes in the midgut cells of Anticarsia gemmatalis (Lepidoptera: Noctuidae). Ecotoxicol Environ Saf 156:1-8 (2018).

29 Finney DJ, Probit Analysis. Cambridge University Press, Cambridge, UK (1964).

30 Originlab Corporation, OriginPro v. 9.0.0 SR2 b87. Originlab Corporation, Northampton, MA (2013).

31 SAS Institute, The SAS System for Windows, Release 9.0. SAS Institute, Cary, NC (2002)

32 Fettig CJ, Hayes CJ, McKelvey SR and Mori SR, Laboratory assays of select candidate insecticides for control of Dendroctonus ponderosae. Pest Manag Sci 67:548-555 (2011).

33 Koppenhöfer AM, Kostromytska OS and Wu S, Pyrethroid-resistance level affects performance of larvicides and adulticides from different insecticide classes in populations of Listronotus maculicollis (Coleoptera: Curculionidae). J Econ Entomol 111:1851-1859 (2018).

$34 \mathrm{Neoh} \mathrm{KB}, \mathrm{Hu}$ J, Yeoh BH and Lee CY, Toxicity and horizontal transfer of chlorantraniliprole against the Asian subterranean termite Coptotermes gestroi (Wasmann): effects of donor: recipient ratio, exposure duration and soil type. Pest Manag Sci 68:749-756 (2012).

35 Grout TG, Stephen PR and Rison JL, Cyantraniliprole can replace malathion in baits for Ceratitis capitata (Diptera: Tephritidae). Crop Prot 112:304-312 (2018).

36 Roditakis E, Skarmoutsou C, Staurakaki M, del Rosario Martínez-Aguirre M, García-Vidal L, Bielza P et al., Determination of baseline susceptibility of European populations of Tuta absoluta (Meyrick) to indoxacarb and chlorantraniliprole using a novel dip bioassay method. Pest Manag Sci 69:217-227 (2013).

37 Thrash B, Adamczyk JJ Jr, Lorenz G, Scott AW, Armstrong JS, Pfannenstiel $R$ et al., Laboratory evaluations of lepidopteran-active soybean seed treatments on survivorship of fall armyworm (Lepidoptera: Noctuidae) larvae. Fla Entomol 96:724-728 (2013).

38 Xu C, Zhang Z, Cui K, Zhao Y, Han J, Liu F et al., Effects of sublethal concentrations of cyantraniliprole on the development, fecundity and nutritional physiology of the black cutworm Agrotis ipsilon (Lepidoptera: Noctuidae). PLoS One 11:e0156555 (2016).

39 Dong J, Wang K, Li Y and Wang S, Lethal and sublethal effects of cyantraniliprole on Helicoverpa assulta (Lepidoptera: Noctuidae). Pestic Biochem Physiol 136:58-63 (2017).

40 Miller JE and Gibson G, Behavioral response of host-seeking mosquitoes (Diptera: Culicidae) to insecticide-impregnated bed netting: a new approach to insecticide bioassays. J Med Entomol 31:114-122 (1994).

41 Fiaz M, Martínez LC, Plata-Rueda A, Gonçalves WG, Shareef M, Zanuncio JC et al., Toxicological and morphological effects of tebufenozide on Anticarsia gemmatalis (Lepidoptera: Noctuidae) larvae. Chemosphere 212:337-345 (2018).

42 Thanispong K, Achee NL, Bangs MJ, Grieco JP, Suwonkerd W, Prabaripai $A$ et al., Irritancy and repellency behavioral responses of three strains of Aedes aegypti exposed to DDT and $\alpha$-cypermethrin. J Med Entomol 46:1407-1414 (2009).

43 Germinara GS, Cristofaro A and Rotundo G, Repellents effectively disrupt the olfactory orientation of Sitophilus granarius to wheat kernels. J Pest Sci 88:675-684 (2015).

44 Plata-Rueda A, Campos JM, da Silva Rolim G, Martínez LC, Dos Santos $\mathrm{MH}$, Fernandes FL et al., Terpenoid constituents of cinnamon and clove essential oils cause toxic effects and behavior repellency response on granary weevil, Sitophilus granarius. Ecotoxicol Environ Saf 156:263-270 (2018).

45 Wasserthal LT, Interaction of circulation and tracheal ventilation in holometabolous insects. Adv Insect Physiol 26:297-351 (1996).

46 Pimentel MAG, Faroni LRDA, Tótola MR and Guedes RNC, Phosphine resistance, respiration rate and fitness consequences in stored-product insects. Pest Manag Sci 63:876-881 (2007).

47 Kliot A and Ghanim M, Fitness costs associated with insecticide resistance. Pest Manag Sci 68:1431-1437 (2012).

48 Corrêa AS, Tomé HVV, Braga LS, Martins GF, Oliveira LO and Guedes RNC, Are mitochondrial lineages, mitochondrial lysis and respiration rate associated with phosphine susceptibility in the maize weevil Sitophilus zeamais? Ann Appl Biol 165:137-146 (2014).

49 Sousa AH, Faroni LRA, Silva GN and Guedes RNC, Ozone toxicity and walking response of populations of Sitophilus zeamais (Coleoptera: Curculionidae). J Econ Entomol 105:2187-2195 (2012). 